\title{
A STUDY OF THE SATISFACTION OF THE POPULATION OF MAJOR LITHUANIAN CITIES WITH PUBLIC TRANSPORT SERVICES
}

\author{
Kristina SAMAŠONOK ${ }^{\circledR 1}$, Aldona JARAŠŨNIENE் ${ }^{2 *}$, Margarita IŠORAITE் 3 \\ ${ }^{1,3}$ Faculty of Business Management, Vilniaus kolegija/University of Applied Sciences, \\ Didlaukio str. 49, 08303 Vilnius, Lithuania \\ ${ }^{2}$ Faculty of Transport Engineering, Vilnius Gediminas Technical University, \\ Plytines str. 27, 10105 Vilnius, Lithuania
}

Received 6 April 2021; accepted 28 May 2021

\begin{abstract}
The article analyzes an evaluation of consumer satisfaction with public transport services in the light of academic literature which highlights the importance of the public transport system and the features of public transport services. The article presents the most influential aspects of public transport services to consumer satisfaction, as evaluated by the residents of major Lithuanian cities. The opportunities for service quality improvements are also presented. In order to examine the elements of consumer satisfaction with public transport services in the major Lithuanian cities, a quantitative analysis was performed and the method of statistical analysis was applied. Student's test was used to compare and analyze the evaluations by the residents of Vilnius and the residents of other major Lithuanian cities. The most influential elements to satisfaction with public transport services and the overall level of satisfaction with public transport services to the residents of major Lithuanian cities $(\mathrm{N}=466)$ were determined. The research results and insights can be applied in planning the improvements of public transport services.
\end{abstract}

Keywords: consumer satisfaction, public transport, public transport services, public transport service quality, estimates.

JEL Classification: R41, R42.

\section{Introduction}

At present, users of public transport services are demanding for more technologically modern and high-quality services. Public services are specific and strive to meet consumer expectations. The public sector is working to adopt good practices from the private sector in the pursuit of consumer satisfaction. The study on public transport services sought to achieve mutual benefits: to meet consumer needs and to make the process of providing public transport services more efficient. The topic of consumer satisfaction with public services is quite widely discussed by both Lithuanian and foreign authors, but there is a lack of analysis by Lithuanian authors about public transport services and consumer satisfaction with them (A. Jeržemskis \& V. Jaržemskis, 2017).

The fundamental goal of the urban transport system is to ensure full freedom of mobility and quality provision of goods and services by combining the aspects of time, convenience, safety, environmental friendliness, and financial efficiency (Baublys \& Vasilis Vasiliauskas, 2011). In order for the system to function smoothly as well as satisfy communication and service needs of all road users and all vehicles, it is crucial to study the problematic areas and apply the necessary proposals in an integrated manner.

The article highlighte concretizes the research problem with the following problematic questions: what factors determine the satisfaction of the population of large Lithuanian cities with the provided public transport services; how to increase the satisfaction of the residents of Lithuania's major cities (henceforward also referred to as residents) with the provided public transport services?

The research objects are the satisfaction of the residents of major Lithuanian cities with the provided public transport services and the possibilities of improving these services.

The objectives of the research are to find out the current levels of resident satisfaction with the provided public transport services, also, based on the assessments of the residents, to estimate the factors which determine the satisfaction with the provided public transport services, and to identify areas for improvement that influence the

*Corresponding author. E-mail: aldona.jarasuniene@vilniustech.lt 
quality of public transport services the most and to suggest possible solutions for improvement as well.

Applied research methods: analysis of scientific literature and quantitative research.

\section{The analysis of consumer satisfaction with public transport services}

The importance of urban public transport is currently rising. Increasing traffic congestion in cities and the growing interest in environmental issues mean that urban public transport is the preferred transport mode in cities (Fitzová et al., 2018; Matulová \& Fitzová, 2018). The planning process and real-time control strategies have been widely studied in recent years, and there are several practical implementations with promising results (Ibarra-Rojas et al., 2015).

Currently Intelligent Transportation System (ITS) is being developed very rapidly, automation and digitization solutions are being adapted, and sustainable transport is being developed with the aim of making operations more efficient (Tumlin, 2012). In recent decades there has been an increasing focus on multimodality in passenger transport, as it has been recognized that combining different modes of transport, creating a basis for their use as well as convenience can increase the impact of sustainable transport and the efficiency of the whole transport system (Singal, 2018).

Public transport users associate issues relating to convenience, cabin environment, and ease of use to perceived quality of service. Perceptions of quality of service tend to vary across socio-economic cohorts, perceptions of service convenience are central in evaluations of overall satisfaction with services (Morton et al., 2016). It is very important to focus on bus frequency design which plays a very important role in urban public transport systems, as reorganizing bus frequencies to meet the actual travel demands is expected to achieve significant savings in cost (Mo et al., 2020).

Public services are provided to the public on a daily basis, with the help of which the connection of the population is facilitated, security is ensured, and socially significant services are provided in the fields of culture, sports, health, and education (Oliver, 2010; Agbor, 2011). Because public services are by their nature focused on the public interest rather than the pursuit of profit, the quality of public services and the efficiency and effectiveness of their provision are determined and demonstrated by the satisfaction of users of these services (Urvikis, 2016). However, due to the complexity and specificity of public services and the versatility of the definitions of quality and satisfaction, the satisfaction of public service users is quite difficult for service providers to achieve (Burkšiene et al., 2017; Mcloughlin \& Batley, 2012). For this reason, it is important to conduct consumer satisfaction surveys to clarify key issues (Skietrys et al., 2008; Filipović et al., 2009).

The provision of services always requires some type of interaction with the user. For example, consumers provide information and feedback, which often requires their physical involvement (Amorim et al., 2016).

The concept of public services may vary from country to country. The complexity of the concept is also determined by the fact that public services are inseparable from public value, public goods, and public interest (Urvikis, 2016; Meynhardt, 2013).

Public goods are defined as goods provided by the state that do not have consumer competition and its benefits are freely available to all citizens (Burkšienė et al., 2017).

Political and economic changes make it increasingly difficult to define public services, as the context created by liberalization and national economic integration processes introduces two new concepts: services of general economic interest and services of general interest (Burkšienè et al., 2017; Badulescu \& Catalin-Adrian, 2012).

The provision of services always requires some type of interaction with the user. For example, consumers provide information and feedback, which often requires their physical involvement (Amorim et al., 2016).

Customer satisfaction with public transport services. In the $21^{\text {st }}$ century consumer satisfaction is increasingly being studied by Lithuanian and world scientists. Research has shown that, in most cases, consumers value feelings and emotions caused by the consumption of a product or service rather than the product or service itself. Therefore, measuring customer satisfaction is a very effective way for an organization to achieve good results because after learning what consumers want and expect it is possible to check whether the products or services provided by the organization meet those expectations. Lee et al. (2016) mentioned that the key factor of success is customer satisfaction, which is highly dependent on the behavior of the direct line providers. Kahwaji and AL Mubayed (2016) defined the relationship between satisfaction and intention to repurchase, which depends on customers' ability to evaluate products or services. The customer satisfaction surverys have opportunities to show positive information about the products consumed by the customers (Kusdibyo \& Februadi, 2019). It is emphasized that the impact of service quality influences customer behavior. The customer satisfaction indicates as the nature of the product may affect satisfaction (Zhu et al., 2010). For Ilieska (2010) customer satisfaction is an asset that should be monitored and managed. Nobar et al. (2010) stated that customer satisfaction is business phil Gilaninia et al. (2013) osophy that demonstrates responsibility and ability to meet customers' needs by managing and anticipating their expectations. While Suchánek et al. (2017) argued that customer satisfaction can be defined using two key terms: transaction reasonable satisfaction and cumulative satisfaction. Minh and Huu (2016) claimed that customer satisfaction is becoming one of the most important goals of every company that considers long-term relationships with customers as a top priority. Yeung and Ennew (2001) stated that customer satisfaction is one of the most commonly measured marketing metrics, thus most major organizations collect data about how satisfied their customers are on a regular basis. 
Gustafsson et al. (2005) mentioned that custom satisfaction used to explain loyalty as a behavioral intent (e.g., probability of redemption and recommendation). VilkaitéVaitone et al. (2016) mentioned that consumer satisfaction research helps identify key determinants of consumer dissatisfaction with the services of an organization, and after each is assessed, appropriate measures can be selected and all efforts can be focused on eliminating the factors which cause dissatisfaction. Research on consumer satisfaction with public services revealed not only consumers' opinions about certain services but also their needs, desires, and expectations (Manzin et al., 2012; Diržytė \& Patapas, 2013; Patapas \& Žilionytė, 2016).

Improving the quality of services is part of policy and strategy development (Morton et al., 2016). Lai and Chen (2011) drew attention to behavioral intentions and examined the relationship between passengers' behavioral intentions and the various factors that affect them. According to Carreira et al. (2014), improving travel experience by promoting differentiation and customer loyalty has become a top priority for transportation companies. Therefore, transport planners, service providers, and manufacturers in general understand the importance of improving transit policy, management, and vehicles in order to provide a better passenger experience. A holistic perspective of travel experience is understood as a comprehensive set of internal passenger responses driven by experience factors, some of which are aspects that are not fully controlled, such as waiting areas or a social environment before, during, and after the trip. Mahmoud and Hine (2016) argue that research needs to assess how consumers perceive service quality as important.

\section{Research methodology}

\section{Research methods}

Academic literature analysis. Scientific literature related to the topic of satisfaction with public services was examined. Research by Lithuanian and foreign scientists is discussed and summarized.

Quantitative method. In order to evaluate the satisfaction of the residents of the major Lithuanian cities with the public transport services, a questionnaire was used. Due to the unique characteristic of public transport services, the measures that allow for the best evaluation of public opinions and satisfaction with the public transport services were chosen. The questionnaire was designed based on the conclusions of the theory analysis, on the analysis of factors which determine customer satisfaction with public transport, and on their components, as they were presented in the scientific literature. The majority of the analyzed authors (Goldstein et al., 2002) distinguished the following factors as underlying conditions for customer satisfaction with public transport services: convenient schedules and adhering schedule, route network arrangement, speed of services, adequate and complete provision of information about timetables, changes, and innovations on websites; therefore, evaluating the convenience and accessibility of services was of the highest importance when designing the questionnaire. Another category of the questionnaire, customer service in public transportation, was based on the research by Lai and Chen (2011) and Carreira et al. (2014), who emphasized the importance for each frontline service provider, i. e., drivers and ticket inspectors, to be professional as well as civilized and polite when interacting with the passengers. According to Manzin et al. (2012), adequate equipment and its technical condition, ticketing and activation system, physical safety of passengers, comfortable public transport vehicles, cleanliness and environmentally friendly transport are several of the factors that have great influence on the satisfaction with the public transport services; therefore, they provided the basis for the category quality of public transport equipment. Mahmoud and Hine (2016) claimed that in order to provide great quality public services and to gain customer satisfaction, peculiarities of each customer, the needs of disabled people who want to use public transport, the needs of parents with young children, or people with pets or bicycles and other modes of transport must to be taken into account; therefore, the category accommodation of different consumer groups in public transport was also included. The statements that were ascribed to this category allowed for the evaluation of such features as accommodation of disabled people and parents with young children, discounts for students and senior citizens, and the possibility to transport pets, bikes, scooters etc. on public transport. The aforementioned categories play a major role in determining the quality and satisfaction of the residents of the biggest Lithuanian cities with public transport services. Due to the fact that convenience and availability of public transport, quality of provided services, quality of public transport equipment, and accommodation of different user groups are some of the most significant features of public transport, all of them must be gauged as one indivisible part of quality of services.

Statistical analysis. The collected data was examined by employing the following statistical analysis methods: descriptive statistics (mean, standard deviation) and Student's test (to compare the means of two independent samples). SPSS software (version 17) was used for the analysis.

Participant sample. The sample contained 466 residents of the major Lithuanian cities, the majority of whom were women $(\mathrm{N}=359$ (76.9 per cent)). Only 107 (23 per cent) participants were men. It was observed that in terms of place of residence, the majority of participant of the survey live in Vilnius ( $\mathrm{N}=315$ (67.6 per cent), while only a third of all participants $(\mathrm{N}=151$ (32.4 per cent) reside in other major Lithuanian cities. The type of the sample convenience sample. The research was based on ethical principles, such as the principles of anonymity and free will to take part in the survey.

In order to analyze in more detail the distribution of the population of Lithuania's major cities according to demographic data, they are presented in Table 1. 
Table 1. Demographic estimates of the respondents

\begin{tabular}{|l|l|l|}
\hline Gender s & \multicolumn{1}{|c|}{ Age group } & \multicolumn{1}{|c|}{ Residence } \\
\hline Male & From 18 to 35 & Vilnius $\mathrm{N}=315(67.6$ percent $)$ \\
$\mathrm{N}=107$ & years $\mathrm{N}=217$ & Kaunas $\mathrm{N}=65(13.9$ percent $)$ \\
$(23.0$ & (46.6 percent) & Klaipėda $\mathrm{N}=49(10.5$ percent $)$ \\
percent $)$ & From 36 to & Šiauliai $\mathrm{N}=22(4.7$ percent $)$ \\
Female & 55years $\mathrm{N}=173$ & Panevěžys $\mathrm{N}=15(3.2$ percent $)$ \\
$\mathrm{N}=359$ & (37.1 percent) & \\
$(76.9$ & From 56 years & \\
percent $)$ & and older $\mathrm{N}=76$ & \\
& (16.3 percent) & \\
\hline
\end{tabular}

Summarizing the demographic characteristics of the population of major Lithuanian cities, it can be seen that a sufficient number of people from various demographic groups participated in the survey, which allowed to obtain a sufficiently objective opinion of respondents on consumer satisfaction with public transport services.

\section{Research data analysis}

After evaluating the quality of public services and the importance of its effectiveness and efficiency for customer satisfaction, the current situation requires to analyze the factors that determine the satisfaction with public transport services, to identify areas for development, and to find out what measures serve as preconditions for the improvement of public transport service quality.

The research results revealed that a significant majority of respondents $(N=418$ (89.5 per cent)) living in Vilnius (90.8 per cent) as well as in other major cities of Lithuania (88.1 per cent) have used public transport services. The latter percentage may have been influenced by the rapid development of public transport route networks.

It is is not in doubt that the importance and need for public transport services in the process of active globalization, when the various modes of public transport connect individual parts of the city into a whole, provide opportunities for faster, more convenient, safer and easier access to the desired object.

When analyzing which aspects are most important in the public transport system (development, accessibility, reliability, professionalism and culture of staff, convenience, technical condition of vehicles and adaptation to different user groups, ticket price, dissemination of information, security, etc.), the analysis of the sample showed that adhering to schedules $(M=9.07)$, convenient schedules $(M=9.05)$, physical safety of passengers in public transport vehicles $(M=8.85)$, and sufficient public transport vehicles $(M=8.83)$ have been evaluated with the highest point estimates (see Figure 1). One of the top goals of public transport infrastructure development is environmentally friendly vehicles, which is also evident in the research results. Those residents of the major Lithuanian cities who participated in the survey also empathized the importance of environmentally friendly public transport vehicles $(M=7.89)$. The results of the statistical analysis revealed that the lowest point estimates were given to wi-fi in public transport $(M=6.28)$ and the possibility to transport pets, bikes, scooters etc. $(M=6.97)$, thus implying that these aspects of public transport services are less valuable to the respondents.

After examining the results on the residents' satisfaction with public transport services, the highest point estimates revealed that the participants of the survey are satisfied with the provision of information about timetables, changes, innovations on websites $(M=7.97)$ and with adequate and complete information $(M=7.83)$ the most (see Figure 1). High point estimates of ticketing system $(M=7.82)$ and adherence to schedule $(M=7.81)$ also indicated contentment of the residents with these features of public transport. The lowest point estimates revealed that the residents of the major cities of Lithuania are least satisfied with the possibility to transport pets, bikes, scooters etc. $(M=6.68)$ and with the possibility to use wi-fi in public transport $(M=6.69)$.

The results obtained corroborate the previous insights that the most important elements for consumers in accessing public transport services are related to the proper planning of the transport system, convenient routes and timetables and their adherence; the importance of these elements is more pronounced in the population group of other large Lithuanian cities.

The comparative analysis of public transport services evaluation by the residents of Vilnius and the residents of other major Lithuanian cities revealed substantial differences between the estimates (Table 2). T-test was performed and the statistically significant differences of the means $(p<0.05)$ showed that the residents from other major Lithuanian cities besides Vilnius gave the highest point estimate evaluations to convenient schedule ( $M=9.48$, $S D=1.38)$, adherence to schedule $(M=9.48, S D=1.36)$, sufficient public transport vehicles $(M=9.19, S D=1.65)$, and route network arrangement $(M=9.07, S D=1.67)$, indicating their importance to the provision of public transport services, whereas respective point estimates of residents of Vilnius were lower: $M=8.83, S D=2.27$; $M=8.88, S D=2.2 ; M=8.66, S D=2.27 ; M=8.62$, $S D=2.23$. The results obtained corroborate the previous insights that the most important elements for consumers in accessing public transport services are related to the proper planning of the transport system, convenient routes and timetables and their adherence; the importance of these elements is more pronounced in the population group of other major Lithuanian cities. The examination of the research results also revealed that polite behavior of the public transport drivers $(M=8.68, S D=1.77)$ and ticket inspectors $(M=8.94, S D=1.68)$ while providing services as well as professionalism of the drivers $(M=9.03$, $S D=1.69)$ are also amongst the most significant aspects of public transport services, as they received higher point estimate evaluations from the residents from other major Lithuanian cities than from the residents of Vilnius. The point estimates of the latter group of respondents were significantly $(\mathrm{p}<0.05)$ lower: $\mathrm{M}=8.07, \mathrm{SD}=2.31$; $\mathrm{M}=8.15, \mathrm{SD}=2.54 ; \mathrm{M}=8.54, \mathrm{SD}=2.29$ respectively. 


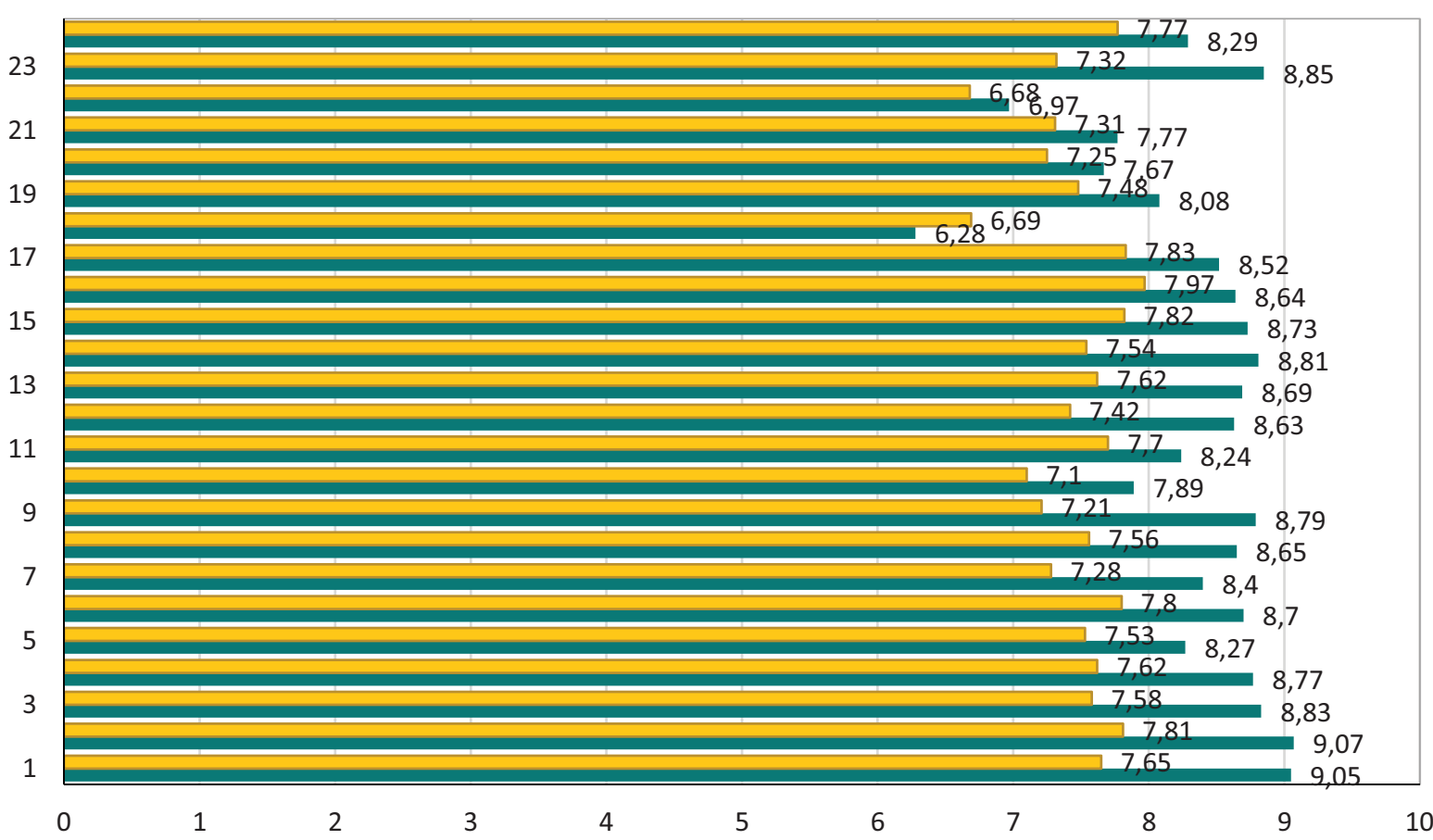

$\square$ The evaluation of the statisfaction with public transport services $\quad$ The evaluation of the importance of public transport services

Figure 1. The evaluation of the satisfaction with public transport services and their importance $((N=466), M-\operatorname{mean}, \mathrm{Max}=10))$

Notes:

1 - Convenient schedule;

2 - Adherence to schedule;

3 - Sufficient public transport vehicles (network) in your town;

4 - Route network arrangement;

5 - Polite behavior of the public transport drivers while providing services (stepping into / off the vehicle, selling tickets etc.);

6 - Professionalism of the drivers;

7 - Polite and respectful behavior of the ticket inspectors;

8 - Comfortable public transport vehicles;

9 - Cleanliness of public transport vehicles;

10 - Environmentally friendly public transport vehicles;

11 - Adequate public transport equipment (ticket activation system, fire extinguishers etc.);

12 - Technical condition of public transport equipment;

13 - Public transport service speed;

Moreover, comfortable public transport vehicles $(M=8.98$, $S D=1.68)$, cleanliness $(M=9.13, S D=1.59)$, adequate public transport equipment (ticket activation system etc.) $(M=8.62, S D=1.86)$, technical condition of equipment $(M=8.95, S D=1.75)$, physical safety in public transport $(M=9.28, S D=1.57)$, ticketing system $(M=9.06$, $S D=1.66)$ were also evaluated as highly important aspects of public transport services by the residents from other major cities besides Vilnius. The same features of public transport received significantly lower $(p<0.05)$ point estimate evaluations from the residents of Vilnius, which suggests that comfortable public transport vehicles $(M=8.49$, $S D=2.21)$, cleanliness $(M=8.63, S D=2.18)$, technical condition of equipment $(M=8.48, S D=2.27)$, physical safety in public transport $(M=8.65, S D=2.28)$, adequate public transport equipment $(M=8.06, S D=2.36)$, and ticketing system $(M=8.57, S D=2.22)$ are less important
14 - Public transport service costs;

15 - Public transport ticketing system;

16 - Provision of information on websites (about timetables, changes, innovations etc.);

17 - Adequate and complete information about timetables, changes, innovations etc. on websites;

18 - Wi-fi in public transport;

19 - Digital passenger information displays with timetables at public transport stops;

20 - Accommodation of disabled people in public transport;

21 - Accommodation of parents with young children in public transport;

22 - Possibility to transport pets, bikes, scooters etc. on public transport; 23 - Physical safety of passengers in public transport vehicles;

24 - Discounts for public transport users (discounts for students, senior citizens etc.).

to the residents of the Lithuanian capital. The point estimate of the question about public transport service speed was significantly higher $(p<0.05)$ in the evaluation of the residents from other major Lithuanian cities $(M=8.99$, $\mathrm{SD}=1.63)$ than that of the residents of Vilnius $(\mathrm{M}=8.55$, $\mathrm{SD}=2.27)$. Moreover, the results of the analysis revealed that significantly lower $(p<0.05)$ point estimates in the evaluations by the residents of Vilnius also apply to the following aspects of public transport services: provision of information on websites (about timetables, changes, innovations etc.) $(M=8.5, S D=2.26)$ and adequate and complete information $(M=8.33, S D=2.31)$. The same aspects evaluated by the residents from other major Lithuanian cities had higher point estimates, $M=8.95, S D=1.75$ and $M=8.92, S D=1.83$ respectively.

The comparative analysis between the residents of Vilnius and the residents of other major Lithuanian cities 
revealed that accommodation of disabled people $(t=-1.048$, $p=0.295)$ and of parents with young children $(t=-1.047$, $p=0.066)$ as well as the possibility to transport pets, bikes, scooters etc. $(t=-0.565, p=0.572)$ are quite similar in terms of their importance. T-test also did not expose a significant difference between the means for discounts for public transport users $(t=-0.597, p=0.551)$ and for public transport service costs $(t=-0.994, p=0.321)$, thus suggesting that both respondent groups evaluated aspects of public transport services directly related with transportation costs rather similarly. Due to statistically insignificant difference $(t=-1.71, \mathrm{p}=0.088)$, the same was observed with the aspect of environmentally friendly public transport vehicles, since the residents of Vilnius $(M=7.7, S D=2.44)$ evaluated the aforementioned feature quite similarly as the residents of other major Lithuanian cities $(M=8.14$, $S D=2.06)$. Also, the point estimate of the public transport feature digital passenger information displays with timetables in public transport stops was significantly higher in the evaluation by residents of other major Lithuanian cities besides Vilnius $(M=8.21, S D=2.23)$ than it was in the evaluation by the residents of Vilnius $(M=8.01$, $S D=2.57)$. In contrast, the residents of Vilnius gave higher point estimate evaluation to the possibility to have wi-fi in public transport $(M=6.38, S D=3.17)$ than did the residents of other major Lithuanian cities $(M=6.09$, $S D=2.94)$. However, t-test did not reveal statistically significant $(p>0.05)$ differences.

Summarizing the results of the research, it can be stated that the accessibility, convenience and ease of use of the

Table 2. Assessment of the importance of provided public transport services in the population groups of Vilnius city $(\mathrm{N}=315)$ and other major Lithuanian cities $(\mathrm{N}=151)(\mathrm{V}$-average values, Max $=10))$

\begin{tabular}{|c|c|c|c|c|c|c|}
\hline & \multicolumn{2}{|c|}{ Residents of Vilnius } & \multicolumn{2}{|c|}{$\begin{array}{c}\text { Residents of other } \\
\text { major Lithuanian cities }\end{array}$} & \multirow{2}{*}{$\mathrm{t}$} & \multirow{2}{*}{$\mathrm{p}$} \\
\hline & M & SD & M & SD & & \\
\hline Convenient schedule & 8.83 & 2.27 & 9.48 & 1.38 & -3.806 & 0.001 \\
\hline Adherence to schedule & 8.88 & 2.2 & 9.48 & 1.36 & -3.596 & 0.001 \\
\hline Sufficient public transport vehicles (network) in your town. & 8.66 & 2.27 & 9.19 & 1.65 & -2.816 & 0.005 \\
\hline Route network arrangement & 8.62 & 2.23 & 9.07 & 1.67 & -2.448 & 0.015 \\
\hline $\begin{array}{l}\text { Polite behavior of the public transport drivers while } \\
\text { providing services (stepping into / off the vehicle, selling } \\
\text { tickets etc.) }\end{array}$ & 8.07 & 2.31 & 8.68 & 1.77 & -3.155 & 0.002 \\
\hline Professionalism of the drivers & 8.54 & 2.29 & 9.03 & 1.69 & 2.571 & 0.011 \\
\hline Polite and respectful behavior of the ticket inspectors & 8.15 & 2.54 & 8.94 & 1.68 & -4.017 & 0.001 \\
\hline Comfortable public transport vehicles & 8.49 & 2.21 & 8.98 & 1.68 & -2.643 & 0.009 \\
\hline Cleanliness of public transport vehicles & 8.63 & 2.18 & 9.13 & 1.59 & -2.823 & 0.005 \\
\hline Environmentally friendly public transport vehicles & 7.77 & 2.44 & 8.14 & 2.06 & -1.71 & 0.088 \\
\hline $\begin{array}{l}\text { Adequate public transport equipment (ticket activation } \\
\text { system, fire extinguishers etc.) }\end{array}$ & 8.06 & 2.36 & 8.62 & 1.86 & 2.758 & 0.006 \\
\hline Technical conditions of public transport equipment & 8.48 & 2.27 & 8.95 & 1.75 & -2.46 & 0.014 \\
\hline Public transport service speed & 8.55 & 2.27 & 8.99 & 1.63 & -2.355 & 0.019 \\
\hline Public transport service costs & 8.75 & 2.1 & 8.95 & 1.82 & -0.994 & 0.321 \\
\hline Public transport ticketing system & 8.57 & 2.22 & 9.06 & 1.66 & -2.688 & 0.007 \\
\hline $\begin{array}{l}\text { Provision of information on websites (about timetables, } \\
\text { changes, innovations etc.) }\end{array}$ & 8.5 & 2.26 & 8.95 & 1.75 & -2.95 & 0.019 \\
\hline $\begin{array}{l}\text { Adequate and complete information about timetables, } \\
\text { changes, innovations etc. on websites }\end{array}$ & 8.33 & 2.31 & 8.92 & 1.83 & -2.972 & 0.003 \\
\hline Wi-fi in public transport & 6.38 & 3.17 & 6.09 & 2.94 & 0.977 & 0.329 \\
\hline $\begin{array}{l}\text { Digital passenger information displays with timetables at } \\
\text { public transport stops }\end{array}$ & 8.01 & 2.57 & 8.21 & 2.23 & -0.829 & 0.407 \\
\hline Accommodation of disabled people in public transport & 7.57 & 2.86 & 7.87 & 2.76 & -1.048 & 0.295 \\
\hline $\begin{array}{l}\text { Accommodation of parents with young children in public } \\
\text { transport }\end{array}$ & 7.61 & 2.93 & 8.1 & 2.55 & -1.047 & 0.066 \\
\hline $\begin{array}{l}\text { Possibility to transport pets, bikes, scooters etc. on public } \\
\text { transport }\end{array}$ & 6.91 & 3.08 & 7.09 & 3.06 & -0.565 & 0.572 \\
\hline Physical safety of passengers in public transport vehicles & 8.65 & 2.28 & 9.28 & 1.57 & -3.479 & 0.001 \\
\hline $\begin{array}{l}\text { Discounts for public transport users (discounts for } \\
\text { students, senior citizens etc.) }\end{array}$ & 8.24 & 2.68 & 8.4 & 2.38 & -0.597 & 0.551 \\
\hline
\end{tabular}


service were assessed by Vilnius residents as less important factors in receiving public transport services than by residents of other major Lithuanian cities and information dissemination methods about the provided services. On the other hand, significant criteria for assessing the quality of transport services are staff culture, courteous behavior and professionalism, as well as a physically safe, tidy and clean environment and the adequacy and suitability of facilities to provide quality services.

In order to create a service that meets the needs of consumers and an efficient public service provision process, it is important to find out the satisfaction of consumers with the provided services, to reveal their needs and expectations.

The comparative analysis of satisfaction with public transport services uncovered variances in evaluations by the two groups of residents from different Lithuanian cities (Table 3). T-test revealed statistically significant high point estimates of adequate public transport equipment (ticket activation system etc.) $(M=8.03, S D=1.81)$ and technical condition of public transport $(M=7.7, S D=1.84)$ in the evaluation by the residents of other major Lithuanian cities, which in turn indicates higher satisfaction of the group with the aforementioned services; whereas in the group of residents of Vilnius the point estimates of the same aspects of public transport were significantly lower $(p<0.05), M=7.55, S D=2.09)$ and $M=7.29, S D=2.01$ respectively. On the other hand, the analysis revealed that the residents of Vilnius are more satisfied with wi-fi in public transport $(M=6.91, S D=2.54)$ and digital passenger information displays with timetables in public transport

Table 3. The evaluation of the satisfaction with public transport services by survey participants from Vilnius $(N=315)$ and other major Lithuanian cities $(N=151)(M-$ mean, $\operatorname{Max}=10)$

\begin{tabular}{|c|c|c|c|c|c|c|}
\hline & \multicolumn{2}{|c|}{$\begin{array}{l}\text { Residents of } \\
\text { Vilnius }\end{array}$} & \multicolumn{2}{|c|}{$\begin{array}{l}\text { Residents of other major } \\
\text { Lithuanian cities }\end{array}$} & \multirow[t]{2}{*}{$\mathrm{t}$} & \multirow{2}{*}{$\mathrm{p}$} \\
\hline & M & SD & M & SD & & \\
\hline Convenient schedule & 7.74 & 2.2 & 7.47 & 2.43 & 1.183 & 0.237 \\
\hline Adherence to schedule & 7.81 & 1.99 & 7.81 & 2.18 & -0.009 & 0.993 \\
\hline Sufficient public transport vehicles (network) in your town & 7.65 & 2.25 & 7.42 & 2.43 & 1.006 & 0.315 \\
\hline Route network arrangement & 7.69 & 2.09 & 7.46 & 2.2 & 1.071 & 0.285 \\
\hline $\begin{array}{l}\text { Polite behavior of the public transport drivers while } \\
\text { providing services (stepping into / off the vehicle, selling } \\
\text { tickets etc.) }\end{array}$ & 7.57 & 2.1 & 7.45 & 2.05 & 0.57 & 0.569 \\
\hline Professionalism of the drivers & 7.82 & 2.04 & 7.77 & 1.97 & 0.239 & 0.811 \\
\hline Polite and respectful behavior of the ticket inspectors & 7.25 & 2.38 & 7.35 & 1.99 & -0.492 & 0.623 \\
\hline Comfortable public transport vehicles & 7.51 & 1.94 & 7.66 & 1.9 & -0.741 & 0.459 \\
\hline Cleanliness of public transport vehicles & 7.09 & 2.21 & 7.46 & 1.95 & -1.794 & 0.073 \\
\hline Environmentally friendly public transport vehicles & 6.98 & 2.2 & 7.34 & 2.0 & -1.683 & 0.093 \\
\hline $\begin{array}{l}\text { Adequate public transport equipment (ticket activation } \\
\text { system, fire extinguishers etc.) }\end{array}$ & 7.55 & 2.09 & 8.03 & 1.81 & -2.586 & 0.01 \\
\hline Technical conditions of public transport equipment & 7.29 & 2.01 & 7.7 & 1.84 & -2.216 & 0.027 \\
\hline Public transport service speed & 7.57 & 2.04 & 7.72 & 2.04 & -0.761 & 0.447 \\
\hline Public transport service costs & 7.6 & 2.17 & 7.42 & 2.31 & 0.803 & 0.423 \\
\hline Public transport ticketing system & 7.7 & 2.19 & 7.91 & 2.06 & -0.655 & 0.513 \\
\hline $\begin{array}{l}\text { Provision of information on websites (about timetables, } \\
\text { changes, innovations etc.) }\end{array}$ & 7.99 & 2.06 & 7.93 & 2.02 & 0.264 & 0.792 \\
\hline $\begin{array}{l}\text { Adequate and complete information about timetables, } \\
\text { changes, innovations etc. on websites }\end{array}$ & 7.83 & 2.12 & 7.81 & 2.15 & 0.128 & 0.898 \\
\hline Wi-fi in public transport & 6.91 & 2.54 & 6.23 & 2.77 & 2.613 & 0.009 \\
\hline $\begin{array}{l}\text { Digital passenger information displays with timetables at } \\
\text { public transport stops }\end{array}$ & 7.65 & 2.15 & 7.13 & 2.68 & 2.118 & 0.035 \\
\hline Accommodation of disabled people in public transport & 7.29 & 2.14 & 7.17 & 2.26 & 0.558 & 0.577 \\
\hline $\begin{array}{l}\text { Accommodation of parents with young children in public } \\
\text { transport }\end{array}$ & 7.36 & 2.15 & 7.21 & 2.3 & 0.69 & 0.491 \\
\hline $\begin{array}{l}\text { Possibility to transport pets, bikes, scooters etc. on public } \\
\text { transport }\end{array}$ & 6.69 & 2.46 & 6.65 & 2.43 & 0.165 & 0.869 \\
\hline Physical safety of passengers in public transport vehicles & 7.29 & 2.17 & 7.38 & 2.15 & -0.399 & 0.69 \\
\hline $\begin{array}{l}\text { Discounts for public transport users (discounts for students, } \\
\text { senior citizens etc.) }\end{array}$ & 7.85 & 2.2 & 7.6 & 2.37 & 1.139 & 0.255 \\
\hline
\end{tabular}


stops $(M=7.65, S D=2.15)$ than the other group of residents. Their evaluations of the same services for this group were $M=6.23, S D=2.77)$ and $M=7.13, S D=2.68$ respectively.

As the statistical analysis of the data showed, although the residents of Vilnius rated the convenience of timetables $(M=7.74)$, the sufficiency of public transport in the city $(M=7.65)$ and the layout of routes $(M=7.69)$ with higher average averages, as well as the professionalism of public transport drivers $(M=7.82)$ and the culture of the latter, polite behavior in serving passengers $(M=7.57)$ and the price of services $(M=7.6)$, provision of information on schedule changes, innovations on the website $(M=7.99)$ and its adequacy and completeness $(M=7.83)$, adaptation of public transport services for the disabled $(M=7.29)$, parents with small children $(M=7.36)$ and opportunities for transporting pets, scooters by public transport whether bicycles $(M=6.69)$ and discounts and benefits for passengers $(M=7.85)$ than those assessed by the residents of other major Lithuanian cities who participated in the survey (see Table 3), who assessed that the latter are more satisfied with politeness and respectful work of controllers with passengers $(M=7.35)$, convenience $(M=7.66)$, cleanliness $(M=7.46)$ and environmental friendliness $(M=7.34)$ of public transport vehicles, as well as physical safety of public transport equipment $(M=7.38)$, speed of services provided $(M=7.72)$ and the ticketing system $(M=7.91)$, but no statistically significant $(p>0.05)$ differences were found between these variables after calculating the t-test. Recent results suggest that respondents are satisfied with the public transport services provided at a similar level regardless of the city in which they live.

The analysis of different dimensions of public transport service quality highlighted the significance of such public transport elements as comfort, safety, speed of service, adequate and complete information about timetables etc., and customer service quality etc. The quality of these elements and the way they are fulfilled determine the overall customer satisfaction with public transport services and whether the customer will use the services in the future.

The statistical analysis of the collected data revealed that the greatest opportunity for public transport improvement lies in increasing effectiveness, as fast and timely service $(M=8.91)$ and infrastructure and proper facilities for waiting, stepping into / off the vehicle $(M=8.91)$ had the highest point estimates (see Figure 2). Other public transport aspects that could improve the satisfaction with public transport services are convenience while using public transport services $(M=8.88)$ as well as tidy and adequate physical environment, suitable for provision of high quality public transport services, for example, cleanliness, physical safety etc. $(M=8.85)$. Such features as digital passenger information displays at public transport stops also received rather high evaluation by the residents $(M=8.83)$, suggesting that improvements in this area of public transport would benefit overall satisfaction with public transport services. In contrast, better wi-fi $(M=7.3)$ and the possibility to coordinate getting around with other modes of transport, such as bicycles or scooters $(M=7.59)$, are not seen as opportunities for improving quality of public transport services. The evaluations of the residents also indicated that professionalism and competence of employees $(M=8.47)$ as well as polite and respectful behavior of the public transport service employees towards passengers $(M=8.43)$ would also have a less influence to the improvement of quality public transport services.

The examination of the data from the residents of Vilnius and the residents of other major Lithuanian cities showed that statistically significant differences were found in seven out of ten categories (Table 4).

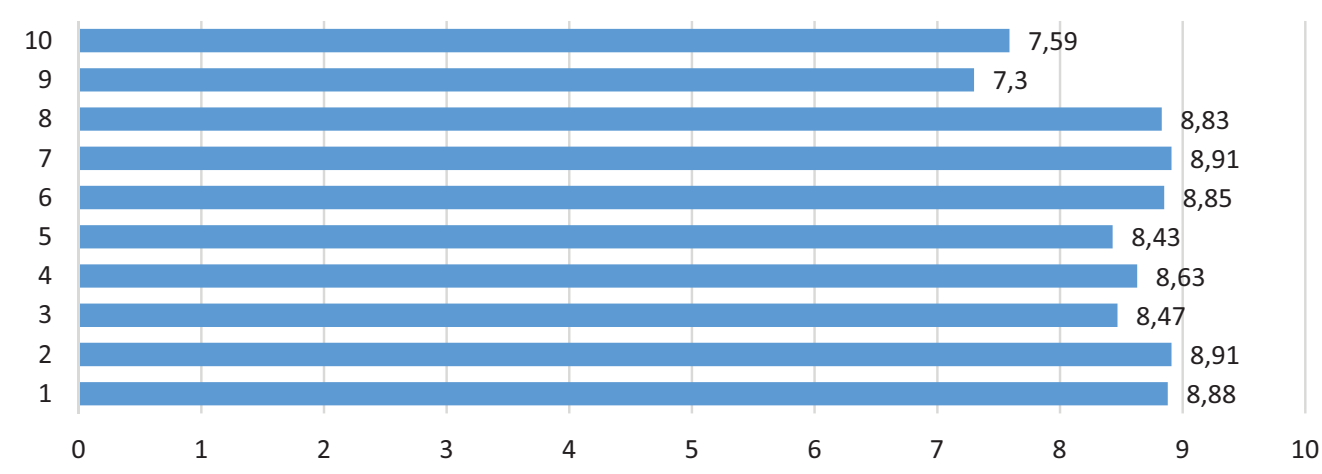

Figure 2. Opportunities for improvement in public transport services: an evaluation by residents of the major Lithuanian cities $(N=466),(M-$ mean, Max $=10))$

Notes:

1 - Convenience while using public transport services (routes, timetables, duration etc.);

2 - Speed of public transport services (effectiveness), fast and timely service;

3 - Professionalism and competence of employees;

4 - Smooth, accurate, and exhaustive provision of information about public transport and related changes (e. g. public transport route and timetable changes);
5 - Polite and respectful behavior of the public transport service employees towards passengers;

6 - Tidy and adequate physical environment, suitable for provision of high quality public transport services (e. g. physical safety, cleanliness etc.);

7 - Infrastructure for waiting, stepping into / off the vehicle;

8 - Digital passenger information displays at public transport stops;

9 - Better wi-fi connection in public transport vehicles;

10 - Coordination with other modes of transport. 
Table 4. Opportunities for improvement in public transport services: an evaluation by residents of Vilniaus $(N=315)$ and other major Lithuanian cities $(N=151)(M-$ mean, Max $=10)$.

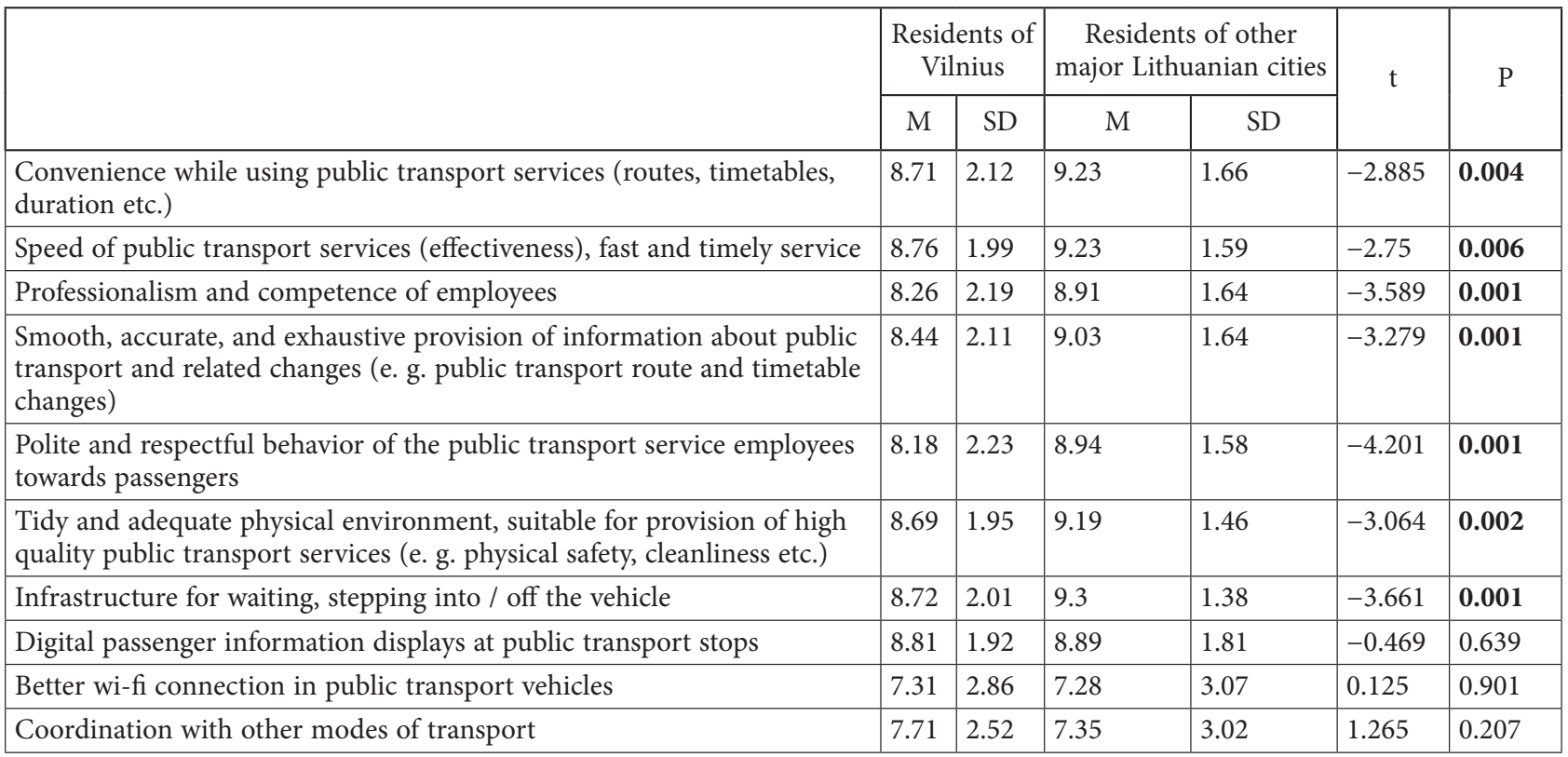

After performing t-test statistically significant higher point estimates $(p<0.05)$ showed that residents from other major Lithuanian cities besides Vilnius believe that convenience while using public transport services (routes, timetables, duration etc.) $(M=9.23, S D=1.66)$ and speed of public transport services $(M=9.23, S D=1.59)$ would improve the quality of public transport services, whereas the residents of Vilnius did not indicate respective features of public transport, $(M=8.71, S D=2.12)$ and $(M=8.76$, $S D=1.99$ ), as significant in improving the quality of services. The statistical analysis also revealed that the residents from other major Lithuanian cities pointed out the importance of professionalism and competence of employees $(M=8.91, S D=1.64)$ as well as polite and respectful behavior of the public transport service empoyees towards passengers $(M=8.94, S D=1.58)$ to improving the quality of public services. In contrast, significantly lower point estimates were found in the results by the group of residents of Vilnius (Table 4). Similar tendencies were observed for other features of public transport. According to the results of the residents of other major Lithuanian cities, tidy and adequate physical environment, for example, physical safety, cleanliness $(M=9.19, S D=1.46)$, infrastructure for waiting, stepping into / off the vehicle $(M=9.3, S D=1.38)$, and accurate and exhaustive information about public transport and related changes $(M=9.03, S D=1.64)$ would also increase the quality of public transport services, whereas the estimates were significantly lower $(p<0.05)$ in the results by the residents of Vilnius: $(M=8.69, S D=1.95)$, $(M=8.72, S D=2.01)$, and $(M=8.44, S D=2.11)$ respectively.

The results of the analysis also showed that both the residents of Vilnius as well as the residents of other major Lithuanian cities hold similar views towards better wi-fi in public transport vehicles $(t=0.125, p=0.901)$, digital passenger information displays at public transport stops $(t=-0.469, p=0.639)$, and coordinating getting around with other modes of transport $(t=1.265, p=0.207)$ as well as their influence on improving the quality of public transport services (Table 4). The significance level of the aforementioned aspects was $p>0.05$.

To summarize, the results of the comparative analysis revealed that the residents of other Lithuanian cities believe that convenience routesa and schedules, fast and timely service as well as accurate and exhaustive information about public transport and related changes would highly influence the quality of public transport. The residents of other major Lithuanian cities also gave higher evaluations to such features of public transport services as professionalism and competence of employees, polite and respectful behavior of the public transport service employees towards passengers, tidy and adequate physical environment, safety, and cleanliness as well as infrastructure for waiting, stepping into / off the vehicle than did the residents of Vilnius. The results of the analysis also indicated that to both the residents of Vilnius and the residents of other major Lithuanian cities better wi-fi and coordination of getting around with other modes of transport are not as influential to improving the quality of public transport services as are the other aforementioned aspects of public transport.

\section{Integrated model for improving consumer satisfaction with public transport services}

Based on the research results, Integrated model for improving consumer satisfaction with public transport services was created (see Figure 3). Such features as convenience, 
accessibility, and speed of public transport are linked with higher satisfaction with the services, which is confirmed by the results of the research, where adherence to schedule and convenient timetables, sufficient amount of public transport vehicles, and proper route network arrangement were identified as the most important aspects when using public transport services. Accuracy, frequency, exhaustiveness, simplicity, sufficiency of public transport information and variety of its channels are important for meeting customer needs. They are a precondition for using public transport services. The importance of these public transport elements was verified by the results of the research. Sufficient and exhaustive information about public transport ant its availability on websites are identified as some of the most important aspects of public transport services. In order to increase the quality of public transport services and customer satisfaction with them, it is crucial to incorporate areas of convenience and accessibility of public transport services and speed, accuracy, frequency, exhaustiveness, simplicity, sufficiency of public transport information into the Integrated model for improving consumer satisfaction with public transport services. People who provide public transport services and their polite and professional demeanor also play an important role in customer satisfaction. The analysis revealed that professionalism and polite behavior of the public transport drivers towards passenger are extremely important; therefore, the category customer service in public transportation is imperative to the model.

Amongst the essential elements which determine the satisfaction with public transport services are cleanliness, good technical condition of public transport vehicles, physical safety of passengers, and suitable equipment for provision of high quality public transport services. The results also revealed that a large majority of the respondents drew attention to the importance of technical condition of equipment, ticketing system, passenger physical safety, and comfortable public transport vehicles. Due to this

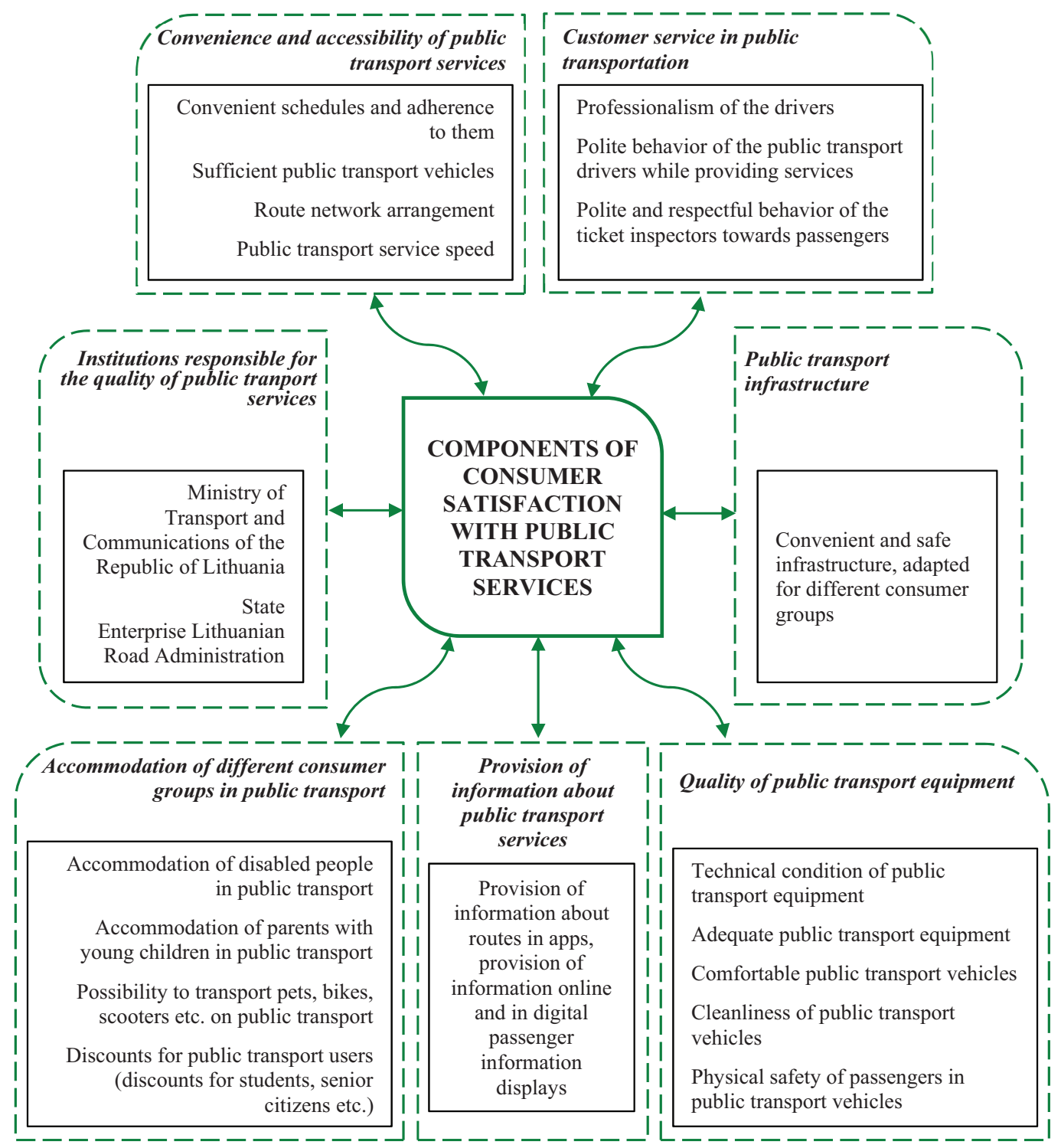

Figure 3. Integrated model for improving consumer satisfaction with public transport services 
observation, a separate category of quality of public transport equipment was introduced to the model. The category of accommodation of different consumer groups in public transport was based on the idea that in order to increase the satisfaction of public transport services, it is necessary to adapt to individual passenger needs by ensuring easy access for disabled people or people with young children as well as for those who want to bring pets, bicycles, or other equipment with them on public transport. The results of the analysis clearly indicated that the aforementioned aspects must be included in the model for public transport service improvement. The model should also include responsibilities and sector activities of the Ministry of Transport and Communications of the Republic of Lithuania and the State Enterprise Lithuanian Road Administration as well as educational institutions.

In order to improve the quality of public transport and to increase the satisfaction with the services, it is crucial to take into account all areas of the Integrated model.

A recommendation for presenting the areas for public transport improvement would be to create a map which shows the levels of customer satisfaction as well as the significance of variables. This method would allow to identify and match public transport features that have relatively high significance with poor consumer satisfaction, thus revealing public transport areas that require improvements.

\section{Discussion}

Recently there has been a growing interest in the issue of consumer satisfaction with public transport services. In order to identify the needs and expectations of public transport users as well as the ways to increase consumer satisfaction, a survey of consumer satisfaction with public transport services in major Lithuanian cities was conducted. Research on consumer satisfaction with public transport services has been also conducted by various of authors, such as (Singh, 1991; Eboli \& Mazzulla, 2008; Amponsah \& Adams, 2016; Anderson et al., 2013; Dragu et al., 2013; Friman \& Fellesson, 2009; Stojic et al., 2020; Hensher et al., 2003). Singh (1991) suggested that there are questions about the structure of satisfaction which are particularly important for services. Unlike products, services are usually intangible, for example, transport services, they often involve the customer in the "production" process, and are provided directly from the supplier to the customer. After examining consumer satisfaction with public transport services in major Lithuanian cities, it was found that the residents of major Lithuanian cities are the most satisfied with the provision of information about timetables, their changes, and innovations on websites and the adequacy and completeness of this information as well as with public transport ticketing system and tools, the adequacy of equipment, such as ticketing system etc., in public transport. Public transport users are least satisfied with the possibilities provided to transport pets, bicycles, scooters etc. and with the possibility to use wi-fi in public transport. Eboli and Mazzulla (2008) stated that the quality of service, particularly in public transport, is of the highest importance because improving quality levels can attract more consumers. Increasing the use of public transport while reducing the use of private cars could help solve many problems, such as congestion, air and noise pollution, and energy consumption. The quality of service is becoming increasingly important for all businesses, including public transport organizations, because it affects customer satisfaction, passenger choice, passenger choice demand, investment decisions, and income (Amponsah \& Adams, 2016; Anderson et al., 2013). The growth of the market share of public passenger transport operators is determined by the quality of services and, in addition, passengers' understanding of the quality provided (Dragu et al., 2013). Friman and Fellesson (2009) stated that important factors, such as reliability, frequency, travel time and ticket price, convenience and cleanliness, network coverage/distance to a stop and safety issues, can be found in the literature which evaluates customer satisfaction with the quality of public transport services. The results of this study showed that for the residents of the major Lithuanian cities who participated in the study adherence to schedules and their convenience, physical safety of passengers in public transport, and adequacy of public transport are among the most important aspects of public transport services. Stojic et al. (2020) suggested that transport efficiency operators and public authorities could be increased if they were more responsive to the needs and requirements of existing customers. Local governments and municipal administrations formulate transport tariffs and provisions for certain social categories. Hensher et al. (2003) claimed that while travelers may perceive the quality of specific services as positive or negative, it can be assumed that the overall level of travel satisfaction is best measured by how a person evaluates the entire package of services proposed.

\section{Conclusions}

1. Public services are essential to every and any social structure. We come across them in public administration and in day to day life. In order to identify public service challenges, it is crucial to analyze the role of consumers and their satisfaction with public services as well as the importance of that level of satisfaction to public services.

2. It was illustrated that high quality research on consumer satisfaction with public services provides responsible authorities with information about relevant challenges, and that information may assist in development of improvement plans.

3. The analysis revealed that for the residents of the major Lithuanian cities, who participated in the research, adhering to schedules and their convenience as well as physical safety of passengers and sufficient 
amount of public transport vehicles are amongst the most important elements when receiving public transport services.

4. The results of a comparative analysis revealed that the following aspects of public transport services are more expressed and more important to the resident from other major Lithuanian cities than to the residents of Vilnius: route network arrangement, adherence to schedules and their convenience, sufficient public transport vehicles, comfortable and clean vehicles, their good technical condition, physical safety while using public transport, adequate public transport equipment, ticketing system, provision of information on websites as well as adequate and complete information, professionalism and polite behavior of the public transport drivers while providing services.

5. The highest point estimates indicated that the residents of major Lithuanian cities are highly satisfied with the provision of information about timetables, changes, and innovations on websites as well as with the amount and exhaustiveness of that information. Moreover, ticketing system, adequate equipment, adherence to schedules, professionalism of the drivers, discounts for passengers, timetable and route network arrangements are also amongst the most influential factors of customer satisfaction with public transport services.

6. The statistical analysis of the data showed that residents from other major Lithuanian cities are more satisfied with public transport equipment and their technical condition than are the residents of Vilnius; however, the latter group is more satisfied with wifi and digital passenger information displays with timetables at public transport stops.

7. The study revealed that fast and timely services, infrastructure, proper facilities for waiting, stepping into / off the vehicle, convenient routes and timetables, tidy and adequate physical environment, suitable for provision of high quality public transport services, cleanliness, and physical safety of passengers would improve the quality of public transport services. A comparative analysis revealed that the estimates for aforementioned features of public transport services and their importance in improving these services are significantly higher in the group of the residents from other major Lithuanian cities than they are in the group of the residents of Vilnius.

8. In order to increase the level of satisfaction with public transport services, it is recommended to consider the services as an integrated and indivisible process. The results of the study revealed that convenience and accessibility of public transport, accuracy, frequency, exhaustiveness, simplicity, sufficiency of information, customer service quality, the quality of public transport equipment, and the accommodation of different passenger groups play a crucial role in customer satisfaction; therefore, they should be taken under consideration when providing public transport services.

9. Partnership, cooperation, and coordination of actions between responsible authorities are a precondition for customer satisfaction with public transport services. The Ministry of Transport and Communications of the Republic of Lithuania, The State Enterprise Lithuanian Road Administration, and The Municipality Enterprise Susisiekimo paslaugos are central figures in the process of improving public transport services, thus activities and responsibilities of these authorities as well as educational institutions should be included in the integrated model, and it is recommended to expand and foster collaborations amongst the institutions as well as to involve them in the processes of improving public transport quality even more.

\section{References}

Agbor, J. M. (2011). The relationship between customer satisfaction and service quality: a study of three service sectors in Umeå. Umeå University, Faculty of Social Sciences, Umeå School of Business.

Amorim, M., Lago, A., Moscoso, P., \& Prieto, E. (2016). Assisted vs. self-checkout in retail: An empirical analysis of the impact of operational process dimensions on customer satisfaction, recommendation and reuse. Journal of Service Science Research, 8, 1-39. https://doi.org/10.1007/s12927-016-0001-z

Amponsah, C. T., \& Adams, S. (2016). Service quality and customer satisfaction in public transport operations. Services and Operations Management, 25(4), 531-549.

https://doi.org/10.1504/IJSOM.2016.080279

Anderson, R., Condry, B., Findlay, N., Brage-Ardao, R., \& Li, H. (2013). Measuring and valuing convenience: a review of global practices and challenges from the public transport sector. In International Transport Forum, Valuing Convience in Publc Transport (pp. 77-110). OECD Publishing. https://doi.org/10.1787/9789282107683-3-en

Badulescu, A., \& Catalin-Adrian, B. (2012). Public services and the euro-regional cooperation. Annals of Faculty of Economics, 1(1), 487-492.

Baublys, A., \& Vasilis Vasiliauskas, A. (2011). Transporto infrastruktūra. Technika. https://doi.org/10.3846/1203-S

Burkšienė, V., Dvorak, J., Burbulytė-Tsiskarishvili, G., Normantè, I., Dūda, M., \& Civinskas, R. (2017). Viešosios paslaugos: iššūkiai kuriant gerovès visuomenę. Mokslo studija [The public services: challenges for the building of a welfare state]. Klaipedos universiteto leidykla. https://hdl.handle.net/20.500.12259/58470

Carreira, R., Patricio, L., Jorge, R. N., \& Magee, Ch. (2014). Understanding the travel experience and its impact on attitudes, emotions and loyalty towards the transportation provider - A quantitative study with mid-distance bus trips. Transport Policy, 31, 35-46. https://doi.org/10.1016/j.tranpol.2013.11.006

Diržytė, A., \& Patapas, A. (2013). Vartotojų pasitenkinimo viešojo sektoriaus paslaugomis ypatumai. Viešoji politika ir administravimas [Public policy and administration], 12(4), 557-566. https://doi.org/10.13165/VPA-13-12-4-03 
Dragu, V., Roman, E. A., \& Roman, V. C. (2013). Quality assessment in urban public transport. Theoretical and Empirical Researches in Urban Management, 8(3), 32-43.

Eboli, L., \& Mazzulla, G. (2008). A stated preference experiment for measuring service quality in public transport. Transportation Planning and Technology, 31(5), 509-523. https://doi.org/10.1080/03081060802364471

Filipović, S., Tica, S., Živanović, P., \& Milovanović, B. (2009). Comparative analysis of the basic features of the expected and perceived quality of mass passenger public transport service in Belgrade. Transport, 24(4), 265-273.

https://doi.org/10.3846/1648-4142.2009.24.265-273

Fitzová, H., Matulová, M., \& Tomeš, Z. (2018). Determinants of urban public transport efficiency: case study of the Chech Republic. European Transport Research Review, 10, 42. https://doi.org/10.1186/s12544-018-0311-y

Friman, M., \& Fellesson, M. (2009). Service supply and customer satisfaction in public transportation: the quality paradox. Journal of Public Transportation, 12(4), 57-69. https://doi.org/10.5038/2375-0901.12.4.4

Gilaninia, S., Taleghani, M., \& Talemi, M. R. (2013). The impact of service quality on customer satisfaction. Journal of Research and Development, 1(4), 1-7.

Goldstein, S. M., Johnston, R., Duffy, J. A., \& Rao, J. (2002). The service concept: the missing link in service design research? Journal of Operations Management, 20(2), 121-134. https://doi.org/10.1016/S0272-6963(01)00090-0

Gustafsson, A., Johnson, M. D., \& Roos, I. (2005 October). The effects of customer satisfaction, relationship commitment dimensions, and triggers on customer retention. Journal of Marketing, 69(4), 210-218.

https://doi.org/10.1509/jmkg.2005.69.4.210

Hensher, D. A., Stopher, P., \& Bullock, P. (2003). Service quality - developing a service quality index in the provision of commercial bus contracts. Transportation Research Part A: 18 Policy and Practice, 37 (6), 499-517. https://doi.org/10.1016/S0965-8564(02)00075-7

Ibarra-Rojas, O. J., Delgado, F., Giesen, R., \& Muñoz, J. C. (2015). Planning, operation, and control of bus transport systems: A literature review. Transportation Research Part B: Methodological, 77, 38-75. https://doi.org/10.1016/j.trb.2015.03.002

Ilieska, K. (2010). Customer satisfaction index - as a base for strategic marketing management. TEM Journal, 2(4), 327331.

Jeržemskis, A., \& Jaržemskis, V. (2017). Keleivinis transportas. Technika. https://doi.org/10.20334/2017-022-S

Kahwaji, A., \& AL Mubayed, M. M. (2016). A study of customer satisfaction dimensions and their impact on customer loyalty to online shopping sites - an analytical study of online shopping sites in Arabic market. IJER, 13(3), 1041-1054.

Kusdibyo, L., \& Februadi, A. (2019). The effect of electronic service quality on customers satisfaction and loyalty in online shopping. In IOP Conference Series: Materials Science and Engineering, 662(2), 022036).

https://doi.org/10.1088/1757-899X/662/2/022036

Lai, W. T.; Chen, C-F. (2011). Behavioral intentions of public transit passengers - The roles of service quality, perceived value, satisfaction and involvement. Transport Policy, 18(2), 318-325. https://doi.org/10.1016/j.tranpol.2010.09.003

Lee, Y.-L., Wang, Y.-Ch., Lu, S.-Ch., Hsieh, Y.-F., Chien, Ch. F., Tsai, S.-B., \& Dong, W. D. (2016). An empirical research on customer satisfaction study: a consideration of different levels of performance. SpringerPlus, 5, 1577.

https://doi.org/10.1186/s40064-016-3208-z
Mahmoud, M., \& Hine, J. (2016). Measuring the influence of bus service quality on the perception of users. Transportation Planning and Technology, 39(3), 1-16.

https://doi.org/10.1080/03081060.2016.1142224

Manzin, M., Žurga, G., \& Mrak, B. (2012). Quality public services dimensions model as a basis for better customer satisfaction management. African Journal of Business Management, 6(26), 7833-7841. https://doi.org/10.5897/AJBM11.2528

Matulová, M., \& Fitzová. H. (2018). Transformation of urban public transport financing and its effect on operators' efficiency: evidence from the Czech Republic. Central European Journal of Operations Research, 26, 967-983. https://doi.org/10.1007/s10100-018-0565-4

Mcloughlin, C., \& Batley, R. (2012). The effects of sector characteristics on accountability relationships in service delivery. In Overseas Development Institute Working Paper No. 350. https://doi.org/10.2139/ssrn.2209074

Meynhardt, T. (2013). Organisations. Entwicklung Zeitschrift für Unternehmensentwicklung und Change Management, 32(4), 4-7.

Minh, N. V., \& Huu, N. H. (2016). The relationship between service quality, customer satisfaction and customer loyalty: an investigation in Vietnamese retail banking sector. Journal of Competitiveness, 8(2), 103-116.

https://doi.org/10.7441/joc.2016.02.08

Mo, S., Bao, Z., Zheng, B., \& Peng, Z. (2020). Bus frequency optimization: when waiting time matters in user satisfaction. Lecture notes in computer science. In C. B. Nah Y., Database systems for advanced applications. DASFAA 2020. Springer, Cham. https://doi.org/10.1007/978-3-030-59416-9_12

Morton, C., Caulfield, B., \& Anable, J. (2016). Customer perceptions of quality of service in public transport: Evidence for bus transit in Scotland. Case Studies on Transport Policy, 4(3), 199-207. https://doi.org/10.1016/j.cstp.2016.03.002

Nobar, K. H. B., \& Rostamzadeh, R. (2010). The impact of customer satisfaction, customer experience and customer loyalty on brand power: empirical evidence from hotel industry. Journal of Business Economics and Management, 19(2), 417-430. https://doi.org/10.3846/jbem.2018.5678

Oliver, R. L. (2010). Satisfaction: A behavioral perspective on the consumer. A behavioral perspective on the consumer. Routledge.

Patapas, A., \& Žilionytė, T. (2016). The public service quality management in Lithuanian municipalities. Public Policy and Administration, 15(2), 206-219. https://doi.org/10.13165/VPA-16-15-2-02

Singal, B. (2018). Public transport planning: a viable integrated multimodal citywide network. India.

Singh, J. (1991). Understanding the structure of consumers' satisfaction evaluations of service delivery. Journal of the Academy of Marketing Science, 19(3), 223-244. https://doi.org/10.1177/009207039101900307

Skietrys, E., Raipa, A., \& Bartkus, E. V. (2008). Dimensions of the efficiency of public - private partnership. Engineering Economics, 58(3), 45-50.

Stojic, D., Ciric, Z., Sedlak, O., \& Horvat, A. M. (2020). Students' views on public transport: satisfaction and emission. Sustainability, 12, 8470(1-16). https://doi.org/10.3390/su12208470

Suchánek, P., Richter, J., \& Králová, M. (2017). Customer satisfaction with quality of products of food business. Prague Economic Papers, 26(1), 19-35.

https://doi.org/10.18267/j.pep.595

Tumlin, J. (2012). Sustainable transportation planning. New Jersey. Urvikis, M. (2016). Vietos savivaldos instituciju organizuojamu 
viešuju paslaugu sistemos tobulinimas [daktaro disertacija, Mykolo Romerio universitetas].

Vilkaitè-Vaitonė, N., Papšienė, P., \& Grikienè, T. (2016). Paslaugų vartotojų pasitenkinimo nustatymas: VŠI „Nacionalinè regionų plètros agentūra" atvejis. Management Theory and Studies for Rural Business and Infrastructure Development, 38(4), 444-452. https://doi.org/10.15544/mts.2016.36

Yeung, M. C. H., \& Ennew, Ch. T. (2001). Measuring the impact of customer satisfaction on profitability: A sectoral analysis. Journal of Targeting, Measurement and Analysis for Marketing, 10, 106-116. https://doi.org/10.1057/palgrave.jt.5740038

Zhu, D-S., Lin, Ch-T., Tsai, Ch-S., \& Wu, J-F. (2010). A study on the evaluation of customers' satisfaction - the perspective of quality. International Journal for Quality Research, 4(2), 105-116. 